\title{
The Canadian Generic Medicines Panel
}

\author{
A Dangerous Precedent in Dangerous Times
}

\author{
Robert HowsE*
}

\section{INTRODUCTION}

Among the most important criticisms of the World Trade Organization that echoed loudly in the protests in Seattle in November 1999 is that the WTO unduly constrains the regulatory autonomy of Member States, defeating or frustrating democratic choices in important areas of social, economic, environmental and cultural policy. When properly interpreted and applied, many WTO rules do, however, permit a considerable amount of regulatory diversity, provided the domestic policies in question do not discriminate against foreigners. The area where the WTO does interfere most explicitly in the ability of governments to strike a balance in their policies between diverse public values is that of intellectual property. The Agreement on Trade-Related Aspects of Intellectual Property Rights does prescribe substantive standards of intellectual property protection, ${ }^{1}$ limiting the ability of democratic polities to strike their own balance between the provision of incentives for innovation on the one hand and consumer welfare on the other; nor are these the only public values at stake, as debates surrounding biodiversity and intellectual property clearly illustrate. Moreover, on a conventional economic analysis, unlike the removal of tariffs, quotas and other overtly discriminatory trade barriers, raising intellectual property protection may actually reduce total domestic and even global economic welfare. For example, in the case of increased patent protection, the additional monopoly rents to producers may generate little additional (efficient) innovation, while creating substantial welfare losses to consumers, who are deprived of cheaper imitations of patented products. ${ }^{2}$ As Maskus suggests:

\footnotetext{
* Professor of Law, University of Michigan Law School, Ann Arbor, Michigan, U.S.A.; and member of the faculty, World Trade Institute, Berne, Switzerland.

A much shorter version of this article appeared in Bridges, the newsletter of the International Centre for Trade and Sustainable Development, April 2000. I benefited from comments by my colleague Becky Eisenberg and my friend Alan Alexandroff on a draft of that shorter piece. I also had the opportunity to present the basic ideas in this article at a Colloquium of the European Studies Center at Harvard Law School on 14 April 2000, and benefited from comments and encouragement from a number of participants in that event. The usual caveat applies.

1 Some people have argued that the Sanitary and Phytosanitary (SPS) and Technical Barriers to Trade (TBT) Agreements also diminish regulatory diversity. However, interpreted correctly, these Agreements create largely procedural requirements for transparent public justification of regulations, and certain related obligations of regulatory consistency and coherence. On SPS, see R. Howse, Democracy, Science and Free Trade: Risk Regulation on Trial at the WTO, Michigan Law Review, forthcoming.

2 As my economics colleague Alan Deardorff has shown: A.V. Deardorff, Should Patent Protection be Extended to all Developing Countries? reprinted in $\mathrm{R}$. Howse (ed.), The World Trading System: Critical Perspectives on the World Economy, Vol. IV, Routledge, London and New York, 1998, pp. 37-48.
} 
"... property rights in information also generate costs. Rent-seeking may be a serious problem because the information is being invented anew and bears no defined ownership until its creation is successful. Thus a strong IPR [intellectual property right] system can encourage both costly duplication of investment in R\&D [research and development] through patent races and wasteful efforts to assert ownership rights and to extend them beyond the intention of the original grant. Further, enforcement costs may be high because it is costly to exclude potential free-riders from exploiting the information. Moreover, excluding prospective users imposes static deadweight costs because the marginal cost of provision is often small. Finally, the costs of transferring rights to intellectual property may be significant because of the contracting difficulties related to uncertainty about the value of information, problems in monitoring licensees, and the like."3

This being said, thanks particularly to the persistent resistance of developing countries to the annihilation of regulatory diversity in TRIPS, the Agreement does contain a balance of rights and obligations, providing some significant scope for Members to circumscribe intellectual property rights in the name of competing public values. ${ }^{4}$ For instance, Article 7 provides that the protection and enforcement of intellectual property rights should contribute not only to the promotion of technological innovation but also to the transfer and dissemination of technology, to the mutual advantage of producers and users of technological knowledge, and in a manner conducive to social and economic welfare, and to a balance of rights and obligations.

\section{The Canadian Generic Medicines Case}

The recent decision of a WTO Panel, in the Canadian Generic Medicines case, ${ }^{5}$ however, ignores these words about balance and mutual advantage, interpreting the patent provisions of the TRIPS Agreement largely from the perspective of intellectual property rights holders, abstracting from competing social interests, and reducing considerably the range of regulatory diversity permitted under TRIPS. At first glance, the decision may appear a victory for those concerned to limit intellectual property rights for compelling reasons of public policy - one of the measures at issue in this dispute, a Canadian provision that allowed competing generic manufacturers to test patented products before the required period of protection expired, was upheld as consistent with the TRIPS Agreement. The companion measure, however, that permitted manufacture and storage ("stockpiling") of patented products before the expiration of the patent so that they can be available for sale immediately upon expiration of the patent, was struck down. Most importantly, the legal interpretations of the TRIPS Agreement constructed by the Panel in this case, if followed in future cases, will have very harmful impacts,

${ }^{3}$ K.E. Maskus, The International Regulation of Intellectual Property, IESG Conference, Regutation of International Trade and Investment, University of Nottingham, Nottingham, U.K., 12-14 September 1997.

+ See, generally, M.J. Trebilcock and R. Howse, The Regulation of International Trade, 2nd edition, Routledge, London and New York, 1999, Ch. 12.

${ }^{5}$ Canada-Patent Protection of Pharmaceutical Products (Generic Medicines), Report of the Panel, WT/DS114/R, 17 March 2000. Not appealed by Canada and now adopted by the Dispute Settlement Body. 
particularly on developing countries, even if Canada's generic medicine industry is largely satisfied by the result of the ruling.

Both Canadian measures were aimed at achieving Canada's long-standing policy goal of providing relatively low cost medication to consumers as soon as possible, consistent with its basic legal obligation under the WTO Agreement to provide twenty years of patent protection. ${ }^{6}$ Early working exceptions of this kind, which facilitate the entry onto the market immediately upon expiration of the twenty-year period of mandated patent protection, have been recognized internationally as one means of achieving these social goals. ${ }^{7}$ The TRIPS Agreement provides that patent rights extend to the ability to prohibit the non-authorized manufacture and use of a patented product (Article 28(1)(a)), and on the other hand reflects the decision of Members to limit the required period of protection under a patent to twenty years (Article 33). The protection that a patent holder receives from a patent is, fundamentally, the protection against competition, i.e. a right to monopoly rents. If it were necessary to prohibit manufacture and use of a patented product by a competitor for the full twenty-year term, the result would be that the stream of monopoly rents to the patent holder would extend beyond the twenty-year period to the length of time after the patent had expired that it took the competitor to engage in testing for regulatory approval and manufacture for the market.

\section{A. The article 30 EXCEPTION}

In defending its measures, Canada relied on the Article 30 exception in the TRIPS Agreement. This provision states that:

"Members may provide limited exceptions to the exclusive rights conferred by a patent, provided that such exceptions do not unreasonably conflict with a normal exploitation of the patent and do not unreasonably prejudice the legitimate interests of the patent holder, taking account of the legitimate interests of third parties."

From this language, the Panel understood Article 30 as containing three separate stipulations, all of which must be met in order for an exception to be taken:

- that the exception be limited;

- that it not unreasonably conflict with a normal exploitation of the patent; and

- that it not unreasonably prejudice the legitimate interests of the rights holder, taking account of the legitimate interests of third parties.

6 On the relevant Canadian legal framework, see Government of Canada, Information-Review of the Patent Act Amendment Act, 1992 (Bill C-91), February 1997, at «http://stragegis.ic.gc.ca/pharmf»; and, generally, P. Kavanos, Health Policy versus Industrial Policy in the Phamaceutical Sector: The Case of Canada, 41 Health Policy 241, 1997.

7 Trans-Atlantic Consumer Dialogue, Recommendations on Health Care and Intellectual Property, Doc. Health 4-00, Early Working of Patents and Research Exceptions; Joint United Nations Programme on HIV/AIDS (UNAIDS), Statement of the Joint United Nations Programme on HIV/AIDS at the Third WTO Ministerial Conference, Seattle, 1999. 


\section{The Meaning of a "Limited Exception" under Article 30}

In applying this provision to the Canadian measures, the Panel first of all considered, in the case of each measure, whether the exception was "limited". It found that the regulatory-testing exception was limited, but not the stockpiling exception. However, it considered the meaning of the expression "limited" solely from the perspective of the rights holder, and without regard to the policy goals or purposes of the exception. ${ }^{8}$ Even though it was dealing with an explicit "exceptions" provision, comprehensible only if there are legitimate, competing policy interests, the Panel was only interested in how much the rights holder might lose, not in how much society might gain, from a given exception. It never asked what scope the exception might require to achieve the social purposes at issue. It thus failed to interpret Article 30 in light of the context, purpose, and object of the TRIPS Agreement, as required by Article 31 of the Vienna Convention on the Law of Treaties. ${ }^{9}$

Had it followed the requirements of the Vienna Convention, the Panel would have had to consider the meaning of the word "limited" in reference to Article 7 of TRIPS, which evokes the mutual advantage of producers and users, the notion of a balance of rights and obligations and, moreover, the notion that protection and enforcement of intellectual property rights should be undertaken "in a manner conducive to social and economic welfare". It also failed to consider the scope indicated by the adjective "limited" in light of the protection of public health, an objective explicitly affirmed as legitimate in Article 8.1 of the TRIPS Agreement. The Panel instead had rapid resort to the negotiating history of the TRIPS Agreement, ${ }^{10}$ a source of treaty interpretation which, according to Article 32 of the Vienna Convention, may only be used in the case that application of the interpretative sources that are obligatory under Article 31 , including the purpose, object and context of the treaty, results in ambiguity or absurdity. ${ }^{11}$

The Panel concluded that the stockpiling exception was not limited, even though there was a time-limit on the exception which allowed it to be used only in the final six months before expiration of the patent and only by those availing themselves of the testing exception. With respect to the six-month cap, the Panel had to admit that this was some kind of limitation, as that was obvious. ${ }^{12}$ However, the Panel adopted the complainant's view that a narrower rather than broader meaning of "limited" should be applied; i.e. "limited" should be read to mean "small". The tenor of this reasoning is exactly contrary to the interpretive principles established by the Appellate Body in

8 ' "... 'limited' is to be measured by the extent to which the exclusive rights of the patent holder have been curtailed.": Generic Medicines, supra, footnote 5, para. 7.31. 679 .

"Vienna Convention on the Law of Treaties, 23 May 1969, 115 U.N.T.S. 331, 8 International Legal Materials

10) Generic Medicines, supra, footnote 5, para. 7.29.

11 Resort to the negotiating history may also be used to confirm an interpretation properly made, based on the sources of interpretation in Article 31 of the Vienna Convention. But this, of course, pre-supposes proper application of Article 31 before resort to the negotiating history.

12 Generic Medicines, supra, footnote 5, para. 7.37. 
Hormones. ${ }^{13}$ There, according to the Appellate Body, the principle of in dubio mitius requires that, where there are two plausible approaches to the interpretation of a treaty provision, the treaty interpreter adopt the interpretation that is less restrictive of the sovereignty of the State or States undertaking the obligation in question. ${ }^{14}$

In justifying its decision to choose the narrower interpretation, the Panel relied on the character of Article 30 as an "exception": since the notion of an "exception" itself suggests a limited right, when the word "limited" is added, the exception must truly be intended to be narrow. The Panel appears to have let assumptions about "exceptions" themselves, being by their nature grudging or confined, influence its reading of the modifying adjective "limited". Thus, it remarks:

"The word 'exception' by itself connotes a limited derogation, one that does not undercut the body of rules from which it is made. When a treaty uses the term 'limited exception' the word must be given a meaning separate from the limitation implicit in the word exception itself. The term 'limited exception' must therefore be read to connote a narrow exception-one which makes only a small diminution of the rights in question."15

This is precisely the kind of interpretation of exceptions that the Appellate Body rejected in the Hormones case. There the Appellate Body held:

“... merely characterizing a treaty provision as an 'exception' does not by itself justify a 'stricter' or 'narrower' interpretation of the provisions than would be warranted by examination of the ordinary meaning of the actual treaty words, viewed in context and in light of the treaty's object and purpose ..."16

As is suggested in this passage, the presumption that exceptions must be read narrowly may be connected to a failure to consider the words of the treaty, in light of its object and purpose. This is precisely the case with the Panel here, which assumed that the basic purpose of the TRIPS Agreement "was to lay down minimum requirements for the protection and enforcement of intellectual property rights". However, as indicated by Article 7 of TRIPS, the basic purpose is not protection and enforcement of these private rights as such, but rather in a manner so as to achieve the mutual advantage of both producers and users and a balance of obligations and rights and to contribute to social and economic welfare. To do justice to this purpose, the Panel would, at a minimum, have had to consider the scope implied in the word "limited" from the perspective not only of how much rights holders' interests were being curtailed but also from the perspective of how limited the exception could be

13 EC Measures Concerning Meat and Meat Products (Hormones), Report of the Appellate Body, WT/DS26/AB/R, WT/DS48/ÅB/R, 16 January 1998.

14 Ibid., para. 165 and accompanying footnote.

15 Generic Medicines, supra, footnote 5, para. 7,309.

16 Hormones, supra, footnote 13. 
while affording sufficient scope to protect public health and the interests of consumers generally. ${ }^{17}$

All this being said, it is something of a mystery as to how the Panel could find the testing exception sufficiently narrow but not the stockpiling exception. In fact, the testing exception could actually much more substantially curtail rents that the patent holder might receive after the end of the twenty-year period than might the stockpiling exception, since the period of testing required as a preliminary for regulatory approval of pharmaceuticals in Canada was three years, much longer than the six-month period for stockpiling. But for the testing exception, the patent holder might have three additional years beyond the twenty-year period of protection to collect monopoly rents, as the competing generic manufacturer would have to wait until the end of the twenty years to begin testing for regulatory approval, thus having to delay an additional three years or so after that before the generic product would have regulatory approval and therefore be competing on the actual market-place. By failing to consider properly the meaning of the word "limited" in light of the object and purpose of the TRIPS Agreement, the Panel was left without an analytical framework which would allow a principled distinction between exemptions that are limited within the meaning of Article 30 and those that are not. The Panel as much as admitted that intuitive linedrawing was what it was doing. ${ }^{18}$

\section{Normal Exploitation of the Patent}

The second condition for taking an exception under Article 30 is that the exception not "unreasonably conflict with a normal exploitation of the patent". Here the Canadian argument was, sensibly enough, that since neither the regulatory testing nor the stockpiling exception interfered with the stream of monopoly rents to the patent holder during the twenty-year-minimum period of protection required by Article 33 of TRIPS, neither unreasonably conflicted with "normal exploitation". Since the Panel had already found that the stockpiling exception was not limited, it did not need to go on to consider whether that exception did not "unreasonably conflict with normal exploitation of the patent", but rather only whether or not the regulatory testing exception did so. Nevertheless, the Panel, in dicta as it were, drew a sharp distinction

17 The Panel does give an explanation of why it considers only the interests of the rights holder. It suggests that Article 30 as a whole should not be interpreted as affecting the balance of rights and obligations established by the other provisions of the TRIPS Agreement, because the "three limiting conditions attached to Article 30 testify strongly that the negotiators of the Agreement did not intend Article 30 to bring about what would be equivalcnt to a renegotiation of the basic balance of the Agreement." (para. 7.26). This is transparently circular reasoning. The Panel interprets the three conditions narrowly because it assumes that Article 30 as a whole docs not affect the balance otherwise established in the TRIPS Agreement, but this general reading of Article 30 depends entirely upon a narrow interpretation of the three conditions! The Panel assumes what it is trying to prove. Thus, the existence of the three conditions in Article 30 would hardly show that it does not affect, or is not part of, the overall balance of the TRIPS Agreement, unless one assumes a narrow view of the conditions.

18 "Without seeking to define exactly what level of curtailment would be disqualifying, it was clear to the Pancl that an exception which results in a substantial curtailment of the dimension [of exclisionary rights granted to patent holders] cannot be considered a 'limited' exccption within the meaning of Article 30 ." In other words, we won't tell you what the legal standard is, but we know that this exception does not meet it. 
between the exceptions as far as normal exploitation went, perhaps aware that the distinction it drew with respect to the first criterion of being limited was conclusory, if not obscure.

In interpreting "normal", the Panel looked exclusively at the expectations of rights holders as to the "economic returns anticipated from a patent's grant of market exclusivity". This again reflects its overall bias in viewing the TRIPS Agreement as having, as its overarching goal, the protection of the rights of innovators, not a balance of rights and obligations between different relevant social and economic interests. Patent holders in general could anticipate that they would enjoy monopoly rents from the patent even beyond the twenty-year period of protection, due to the ability to prevent manufacturing of the product from beginning before the end of that period and the consequent delay in getting the product to market until sufficient product is manufactured. Thus, the monopoly rents obtained after the twenty-year period until the competitor is able to come to market with its stock constituted part of normal exploitation.

If one were to examine the meaning of "normal", however, from the perspective of those interests that dictated a limit on the period of protection required by TRIPS to twenty years, a quite different answer might result; these interests might well anticipate that in establishing a maximum of twenty years of required exclusion of competition, the Trips Agreement allows Members to ensure that the significant social and economic benefits of a competitive market-place begin to flow immediately following the expiry of the required twenty-year period of monopoly. Recognition of the significance of the levels of protection in the TRIPS Agreement as a maximum required under WTO law is to be found in Article 1.1 of TRIPS, which explicitly states that Members shall not be "obliged to, implement in their law more extensive protection than is required by this Agreement, provided that such protection does not contravene the provisions of this Agreement." This provision would be largely ${ }^{19}$ inutile or tautological unless there were some possibility that, in certain circumstances, the operation of dispositions of the TRIPS Agreement, taken together, could have the effect of conferring, overall, more extensive protection than that provided as a matter of law by each individual provision. As a study for the World Health Organization notes:

"These general provisions were included in the Agreement to make for a balance between the rights of patent holders and their obligations vis-à-vis society. Member States may therefore base certain particular provisions of their national regulations on these provisions." 20

The case at hand is a perfect illustration of this. Article 33 of TRIPS provides a legal

19 It might still arguably be used to reinforce an action under GATT law, complaining of unilateral trade measures against a Member in response to its failure to adopt higher levels of protection than those required by the TRIPS Agreement. See Trebilcock and Howse, supra, footnote 4, p. 323. However, the main point is that the treaty interpreter should not lightly assume an interpretation of a treaty provision that renders it inutile within the treaty instrument that contains the provision, in this case the TRIPS Agreement, which is an independent legal instrument.

20 World Health Organization, Action Programme on Essential Drugs, Globalization and Access to Drugs: Perspectives on the WTO/TRIPS Agreement, Health Economics and Drugs, DAP Series No. 7, Revised, 1999, p. 10. 
guarantee of monopoly rents (i.e. exclusion of competition) for a twenty-year period. However, the operation of Article 28, by including the right to prohibit making or using in the patent right, acts in combination with Article 33, to provide effective monopoly rents beyond the twenty-year period guaranteed as a matter of law by Article 33. In such a circumstance, what TRIPS, Article 1.1 tells us is that a Member may act to avoid the operation of the TRIPS Agreement from leading to effective protection in excess of that explicitly and legally guaranteed in the Agreement, which is, in this case, twenty years of monopoly rents. And this gives a coherent meaning to "normal exploitation", namely exploitation within the limited period of market cxclusivity explicitly guaranteed to the patent holder by law in Article 33 .

In explaining why the Canadian regulatory testing exception fit within the Panel's notion of "normal", while the stockpiling exception would not, the Panel made the following observation:

"Some of the basic rights granted to all patent owners, and routinely exercised by all patent
holders, will typically produce a certain period of market exclusivity after the expiration of
a patent. For example, the separate right to prevent 'making' the patented product during
the term of the patent often prevents competitors from building an inventory needed
to enter the market immediately upon expiration of a patent. There is nothing abnormal
about the more or less brief period of market exclusivity after the patent has expired. The
Panel considered that Canada was on firmer ground, however, in arguing that the additional
period of de facto market exclusivity created by using patent rights to preclude submissions
for regulatory authorization should not be considered 'normal'. The additional period of
market exclusivity in this situation is not a natural or normal consequence of enforcing
patent rights. It is an unintended consequence of the conjunction of the patent laws with
product regulatory laws, where the combination of patent rights with the time demands of
the regulatory process gives a greater-than-normal period of market exclusivity to the
enforcement of certain patent rights." 1 (1)

This distinction may be artificial. The time required to build an inventory for sale subsequent to the expiry of the patent may well reflect the need to use production methods that respond to requirements for safety and quality in production, the same regulatory concerns that, ultimately, underlie a lengthy period of testing prior to regulatory approval. Moreover, the ability of producers to build inventory rapidly, while ensuring quality and safety, may well differ depending upon levels of economic development. In the Canadian case, the time needed was apparently around three weeks - but one could not assume the same for generic producers in developing countries, where (ironically), given the weak purchasing power of the vast majority of consumers, any delay in the marketing of generic products at a lower cost might have significant health consequences, if not in certain cases deadly ones. It is significant in this respect that, while most of the developed countries who intervened as third parties in the litigation, most notably the United States and Japan, viewed the stockpiling provision as different from the testing provision, and not justifiable under Article 30, the developing country intervenors, including Brazil, Ecuador, Cuba and Thailand,

21 Generic Medicines, supra, footnote 5, paras. 7.56 and 7.57. 
generally saw the two provisions as linked, and viewed both as acceptable under Article 30.

Finally, by limiting those early working exceptions that are consistent with normal exploitation to those connected with government requirements for regulatory approval, the Panel in effect excluded the possibility of early working exceptions for purposes of scientific research. There may be important social gains from allowing such research activity during the period in which the rights holder is enjoying monopoly rents from the patent. ${ }^{22}$ It is to be noted, however, that, in discussing the meaning of "legitimate interests", the third criterion for an Article 30 exception (discussed in the next section of this article) the Panel cited scientific research as among those legitimate interests that might need to be balanced against those of the patent holder. Perhaps the Panel felt that in an appropriate case, even though a scientific research exception did interfere with normal exploitation of the patent, it might nevertheless not do so unreasonably. Thus, although it will make justification of scientific research exceptions more difficult under TRIPS, the Panel's approach to the meaning of "normal exploitation" may not exclude altogether the possibility of such exceptions being legal under TRIPS, given that Article 30 does permit interference with normal exploitation that is not "unreasonable".

\section{Legitimate Interests}

The third condition for taking an exception under Article 30 is that the exception "not unreasonably prejudice the legitimate interests of the patent owner, taking into account the legitimate interests of third parties". In considering whether this criterion was met with respect to the regulatory-testing exception, which had now passed the first two criteria, the Panel once again displayed its myopic focus on the interests of the rights holder. Here, this bias is even more dramatic, since the very language of the provision indicates the need to balance diverse social and economic interests. Thus, for the Panel, the fact that the "legitimate interests of the rights holder" is mentioned first, indicates a logical sequence, a lexical priority as it were. One cannot even begin to consider what third-party interests might be without first of all ascertaining "the legitimacy and weight of the patent owner's legitimate interests." 23 This provides a route for avoidance of any kind of real balancing-one can silence competing social and economic interests entirely by starting off with defining the rights holder's interests as so weighty or fundamental that other legitimate interests cannot possibly outweigh the prejudice to rights holder's interests.

In interpreting the word "legitimate" in Article 30, the Panel once again did not fulfill the obligations of a treaty interpreter under Articles 31 and 32 of the Vienna Convention. Without considering whether it could render a correct interpretation of the expression "legitimate" on the basis of the sources of treaty interpretation that are

${ }^{22}$ R. Eisenberg, Patents and the Progress of Science: Exclusive Rights and Experimental Use, 56 University of Chicago Law Review 1017, 1989.

${ }^{23}$ Generic Medicines, supra, footnote 5, para. 7.60. 
obligatory under Article 31 of the Vienna Convention, it had recourse to the negotiating history of the TRIPS Agreement, a supplemental means of interpretation that, according to Article 32 of the Vienna Convention, may only be resorted to in the case of ambiguity or absurdity resulting from the application of Article 31 sources of interpretation, or to confirm an Article 31-based interpretation. Of course, obligatory sources of interpretation under Article 31 include the "context": the full text of the treaty itself, including the Preamble. ${ }^{24}$

The first step of the Panel in determining what interests are legitimate within the meaning of Article 30 of TRIPS should thus have been to consider whether there are interests recognized as legitimate in the TRIPS Agreement itself. These interests include, inter alia, "the mutual advantage of producers and users of technological knowledge" (Article 7, emphasis added); "public health and nutrition" (Article 8); and "the public interest in sectors of vital importance to socio-economic and technological development" (Article 8). With respect to patents in particular, Article 27.2 of TR.PS lists such competing interests as "ordre public or morality"; "human, animal or plant life or health"; and avoidance of "serious prejudice to the environment". All these interests are given legal weight in the TRIPS Agreement. Moreover, had it followed the practice of treaty interpretation required by the Vienna Convention, the Panel, in considering the language "mutual advantage of producers and users of technological knowledge", would have understood that the legitimate interests of the patent holder are not to be considered prior to other interests, but inherently in relation to those other interests, particularly those of users of technological knowledge.

However, the damage done by the Panel with respect to its application of the "legitimate interests" criterion is rather limited. It came to the conclusion, based on various negotiating documents, including those related to legal instruments other than the TRIPS Agreement, including the Berne Convention (on copyright!) that legitimate interests of the patent holder did not, as the EC asserted, mean the legal rights of the patent holder as defined in Article 28 of the TRIPS Agreement, but that it had some kind of broader meaning, however ill-defined. The Panel knew what the patent holder's legitimate interests were not, even if it lacked clarity on what they were-and since they were not what the EC said they were, it was able to avoid actually examining the balance between these and other legitimate interests by simply viewing the $\mathrm{EC}$ as not having proven the first step of its legal argument.

The EC, however, made a second claim about "legitimate interests". This was the claim that, in fact, patent holders themselves enjoy less than twenty ycars effective protection, because of the regulatory-approval requirements they are subject to. According to the EC, being able to obtain monopoly rents beyond the twenty-year patent period, while marketing of the generic product is delayed due to regulatory approval, merely compensates for the original delay to which the patented product itself is subject for regulatory-approval purposes.

24 Vienna Convention, supra, footnote 9, Article 31.2. 
Here, in order to determine whether the interest of the patent holder in compensation for its own loss of monopoly rents during the twenty-year period due to regulatory-approval delays was "legitimate", the Panel examined how this problem was treated in a number of jurisdictions in developed countries. It noted that some jurisdictions had increased the term of protection beyond twenty years, but others had not, in response to this concern about the effects on the patent-holder's exclusive rights due to regulatory-approval delays. ${ }^{25}$

The Panel noted correctly that, where governments had not extended the patent term for these reasons, "these government decisions may represent either disagreement with the normative claim made by the EC in this proceeding, or they may simply represent a conclusion that such claims are outweighed by other interests." 26 Without any supporting reasoning, the Panel simply agreed with Canada that the interest of the patent holder was not "legitimate" at all. It merely asserted that to be legitimate an interest has to be "compelling" and widely recognized (presumably in domestic legislation). ${ }^{27}$ This conclusion displays the damage that the Panel's interpretive approach has done to the fundamental structure of Article 30-if the patent holder's legitimate interests means a compelling interest, how can it then ever not trump the other legitimate interests to be taken account of under Article 30? The notion of wide recognition should raise some red flags as well-if wide recognition by governments is substituted for recognition within the TRIPS Agreement itself (the correct approach to interpreting "legitimate" on the basis of Article 31 of the Vienna Convention) as the criterion for legitimacy, what about interests recognized only, for instance, by developing countries as legitimate, not developing ones?

The TRIPS Agreement allows the economic interests of rights holders to be taken into account as legitimate, and indeed in the earlier stages of its analysis, ironically, the Panel itself viewed these as not only more legitimate, but actually primary and paramount. This is arguably even implicit in the description of intellectual property rights as "private rights" in the Preamble to the TRIPS Agreement. However, the extent to which such interests are recognized as legitimate is circumscribed by Article 7, which refers to "mutual advantage" of rights holders and users of technology. Thus, the economic interests of the rights holders cannot be given a status as "legitimate interests" that defeats the "advantage" of users of technology.

An appropriate interpretation of Article 30 in this case would have accepted the interests of the rights holders as "legitimate to an extent", but would have examined whether the Canadian exceptions caused unreasonable prejudice to these interests, taking account of the legitimate interests of third parties. Here, Canada argued that these third-party interests were above all the health interests of its citizens. Would the Panel here have to conduct some kind of open-ended, undisciplined balancing of legitimate

\footnotetext{
25 Generic Medicines, supra, footnote 5, para. 7.78 .

26 Ibid., para. 7.80 .

27 Ibid., para. 7.82.
} 
rights holders' economic interests against the interests of health? ${ }^{28}$ Arguably not. The Vienna Convention includes among the obligatory sources of treaty interpretation in Article 31.3.c, "any relevant rules of international law applicable in relations between the parties". In interpreting the nature of "health" as a legitimate interest within the meaning of Article 30 of TRIPS, it would be appropriate to consider, first of all, that public health is one of those interests explicitly indicated in Article 8.1 to be capable of being advanced "consistent with the provisions of this Agreement". Thus, Article 8.1 precludes a reading of the provisions of the TRIPS Agreement that would make those provisions inconsistent with the right to adopt measures necessary to protect public health. ${ }^{29}$ Then, pursuant to Article 31.3.c of the Vienna Convention, to determine the meaning of "necessary to protect public health", one would have recourse to relevant international health law. In interpreting the scope of "exhaustible natural resources" as a legitimate interest protected by Article XX(g) of the GATT, the Appellate Body took a broad view of the sources of international law that could be appropriately used to articulate the relevant evolving international legal order, including "soft law" sources, such as resolutions and authoritative reports and policy statements of relevant international organizations. ${ }^{30}$

World health policy explicitly endorses measures aimed at rapid market availability of generic medicines. Thus, in a recent speech, Dr Gro Harlem Brundtland, DirectorGeneral of the World Health Organization, declared:

"WHO supports implementation of the TRIPS Agreement to ensure prompt availability of generic drugs upon patent expiration. WHO has long promoted use of generic drugs of assured quality. Experience from countries with 'generic-friendly' policies clearly demonstrates that the market competition created by these policies increases the affordability of medicines, stimulates true innovation with the research-based industry, and encourages increased production efficiency by the generic industry." 31

28 This kind of exercise would entail the Panel engaging in a judgment on complex and sometimes conflicting expert opinions concerning the effect of competition from generics on drug prices. For a clear statement of the complexities of such an analysis, and the variables at issue, see K. Maskus, Price Effects and Competition Aspects of Intellectual Property Rights in Developing Countries, Background Paper for 1998 World Development Report, The World Bank, Washington, D.C., 12 January 1998, pp. 4-8. See the divergent views in P. Challu, The Consequences of Product Patenting, 15 W. Comp. 2, December 1991, p. 65, and in R. Rozek and R. Berkowitz, The Effects of Patent Protection on the Prices of Pharmaceutical Products - Is Intellectual Property Protection Raising the Drug Bill in Developing Countries? 1 J.W.I.P. 2, March 1998, p. 179.

29 There is an alternative reading of Article 8.1, which is that it merely states that Members may take whatever measures necessary to protect public health are consistent with the provisions of the TRIPs Agreement. However, read in this way, Article 8.1 would be meaningless. It would simply say that what is not prohibited under the Agreement is permitted. Since it is a fundamental principle of international law that the sovereignty of States is plenary, except to the extent circumscribed by international law itself, Article 8.1 read this way would be totally redundant and superfluous. See, generally, The Case of the S.S. Lotus (France v. Turkey), Permanent Court of International Justice (1927), P.C.I.J. Ser. A, No. 10. It is also possible that Article 8.1 might be used to reinforce a WTO action under the GATT complaining of unilateral trade measures targeted towards pressuring a Member to refrain from policies that are consistent with the TRIPS Agreement: see Trebilcock and Howse, supra, footnote 4 , p. 323. However, Article 8.1 should be presumed to have some legal significance within the four corners of the TRIPS Agreement itself, which is a separate legal instrument.

30 United States-Import Prohibition of Certain Shrimp and Shrimp Products, Report of the Appellate Body, 12 October 1998, WT/DS58/AB/R, paras. 128 and 130.

31 Worl. Health Organization, Office of the Director-General, International Trade Agreements and Public Health: Who's Role, Conference on Increasing Access to Essential Drugs in a Globalized Economy, Amsterdam, 25-26 November 1999. 
As already noted, early working exceptions have been supported by the Secretariat of the Joint United Nations Programme on Hiv/AIDs. ${ }^{32}$

Thus, world health policy, as evidenced in recent authoritative statements from the leadership of international institutions responsible for health, suggests that the protection of public health entails, among other measures, early working exceptions for patents. To read Article 30 consistently with world health policy would mean giving clear priority to the legitimate health interests in question over any competing interests of the rights holder; if the reference to public health in Article 8.1 of TRIPS is to have any significance at all, it must surely be that the specific provisions of the TRIPS Agreement should be read in a manner consistent with what is required for the protection of public health, as defined by world health policy.

\section{B. THE RELATIONSHIP BETWEEN ARTICLE 30 AND THE ARTICLE 27 NON-DISCRIMINATION REQUIREMENT}

Perhaps most damaging of all to the legitimate balance of rights and obligations in the Trips Agreement is the Panel's finding, despite the lack of a textual basis for any such limit, that exceptions under Article 30 cannot include exceptions to the nondiscrimination provisions in Article 27.1 of the TRIPS Agreement. These nondiscrimination provisions are very different from those typically found in other WTO treaties, which prohibit discrimination between domestic and foreign products and services. Article 27.1 of the TRIPS Agreement prohibits discrimination, inter alia, with respect to "field of technology". However, based on legitimate social and economic objectives, a Member may well wish to limit intellectual property rights in one particular industrial sector-generic medicines is of course a classic example. The importance of health concerns in this sector might well argue in favour of limits that it would be inappropriate to impose across the board on all sectors. Across-the-board imposition might create totally unnecessary costs for both domestic and foreign industries in those sectors - unnecessary in terms of the policy purposes of the measures in question. Thus, according to the Trans-Atlantic Consumer Dialogue:

"Article 27.1 should not be interpreted as requiring a 'one size fits all' patent law. The language in $27.1 \ldots$ should not be interpreted as preventing countries from addressing public interest concerns in patents, when provisions to address those public interest concerns are consistent with the TRIPS framework. Article 30 of the TRIPS regarding exceptions to patent rights should be interpreted to permit countries to address public interest concerns, including those specifically related to fields of technology." 33

The Panel was able to miss entirely the implications for research and development of its treatment of manufacturing under Article 30 because of its general indifference to the purposes that underlie the taking of exceptions under that Article.

The Panel's reasoning on this issue is totally perverse-it claims that Article 27.1

32 Joint United Nations Programme on Hiv/AIDS, supra, footnote 7.

33 Trans-Atlantic Consumer Dialogue, supra, footnote 7. 
limits the Article 30 exception because there is nothing in Article 30 that says otherwise. But, where there is no explicit qualification to an exception, one should assume that the exception applies generally to its explicit subject-matter, which is, in this case, patent rights. Throughout the TRIPS Agreement, where the parties wished to qualify a right or obligation in a particular provision by making it conditional on some other provision of the Agreement, they employed the formula that the right or obligation is "subject to" that other provision. ${ }^{34}$ The Panel suggests that:

"It is quite plausible, as the EC argued, that the TRIPS Agreement would want to require governments to apply exceptions in a non-discriminatory manner, in order to ensure that governments do not succumb to domestic pressure to limit exceptions to areas where right holders tend to be foreign producers." 35

However, if the requirement with respect to non-discrimination on the basis of sector of technology were aimed at preventing this kind of discrimination against foreign producers, it would be superfluous, for Article 27.1 quite independently prohibits discrimination based on "whether products are imported or locally produced".

The interpretive error of the Panel here is related to its earlier interpretive error conccrning the meaning of "taking account of the legitimate interests of third parties". When interpreted properly, this requirement of Article 30 would be hardly likely to be met in the case of an exception that was limited in such a way as to result in a lack of even-handedness as between the treatment of domestic and foreign producers.

To some extent, the Panel repaired the damage done by its forced reading of the relationship of Article 27.1 to Article 30 by finding that the Canadian measure did not violate Article 27.1 because, although it was applied only to the pharmaceutical sector, the statutory provision itself was framed in general terms. ${ }^{36}$ This approach leaves it up to the Panel to determine on a case-by-case basis when a general non-sector-specific exception applied in practice to only one sector constitutes a sham in respect of the nondiscrimination obligation in Article 27.1. This reduces the legal security of both rights holders and those social interests seeking to limit intellectual property protection, and increases the scope for panels to make intuitive, sniff-test-type judgments about when inappropriate discrimination is occurring.

\section{CONClusion}

By failing to interpret the TRIPS Agreement in a manner that does justice to the delicate balance of social and economic interests reflected in the stated purposes of that Agreement, the Panel has crafted a set of readings that unduly curbs the regulatory autonomy of Members and that will undermine the legitimacy of the WTO in the eyes of its critics at a difficult point in the Organization's history. Despite the far-reaching implications of this decision, particularly for the systemic concerns of developing

\footnotetext{
34 This formula is employed in Articles 6,27.1,36 and 65.1.

35 Generic Medicines, supra, footnote 5, para. 7.92.

36 Ibid., paras. 7.98 and 7.99 .
} 
countries about TRIPS, critics should not, however, allow this ruling to obscure other developments in WTO jurisprudence favourable to a balanced and sensitive reading of TRIPS. For instance, the recent Panel on Section 301 of the U.S. trade legislation ${ }^{37}$ took a sensitive view of the extent to which WTO panels should micro-manage the choices of Members in reflecting WTO obligations in their domestic law, suggesting that one could not consider whether a statute adequately implemented WTO obligations without looking at other elements in a Member's domestic legal and administrative landscape, such as constitutional rules and declarations of the authorities as to how the statute might be read or applied. While the Panel did not contradict any proposition of law established by the Appellate Body in the Indian Patents case, ${ }^{38}$ it did produce an analytical optic much less intrusive of domestic sovereignty than that through which the Panel in Indian Patents viewed the evidence of compliance with WTO law in that case. Thus, not all the recent news from Geneva is bad.

37 United States-Sections 301-310 of the Trade Act of 1974, Report of the Panel, 22 December 1999, WT/DS152/R (adopted).

38 India-Patent Protection for Pharmacentical and Agricultural Chemical Products, Report of the Appellate Body, WT/DS50, 16 January 1998. 